\title{
良導絡自律神経調整治療の痙性抑制効果 に対する検討一筋訓練測定装置を用いて
}

\author{
国立療養所札幌南病院 神 経内科 ○中根一好、武井麻子 \\ 土井靜樹、島 功二 \\ 理学療法科 浅賀忠義 \\ 北海道大学病院 神 経内科 田代邦雄
}

\section{要 旨}

我々は良導絡治療の痤性麻疸に対する痙性抑 制効果を定量的に評価する目的で筋訓練測定装 置 KIN-COM $500 \mathrm{H}$ (米国 Chattecx 社製)を 用い評価し検討したので報告する。

対象は痙性対麻痺患者 2例。方法は筋訓練測 定装置の筋電図解析機能を用い、患者の膝関節 を他動的に屈曲伸展させ、大腿四頭筋と八ムス トリングより得られた筋電図所見を本治療前後 で評価した。結果 : 両例共、治療前後で明らか な筋活動電位の減少を認めた。内 1 例で自覚症 状の改善を認めた。結語：本療法は痤性抑制の 一治療手段として有用である可能性を示唆し た。

\section{目 的}

良導絡自律神経調整療法（鏚治療）の痤性抑 制効果に対する定量的検討

\section{方 法}

筋訓練測定装置 (KIN-COM) の筋電図解析 機能を用い良導絡治療前後での下肢痤性抑制効 果を定量的に検討した。

\section{筋訓練測定装置}

筋緊張異常のある患者の関節を他動運動モー ドの設定できる装置で他動的に屈曲伸展させ、
その動きに対する主動筋と拮抗筋の筋電図を記 録評価する機能を備えた装置である。

具体的設定条件として患者を坐位にさせ、左 下肢の大腿四頭筋、及びハムストリングに表面 電極を各 2 個ずつつけ、膝関節を中心に他動的 に動かす。他動的運動範囲として肢位は膝屈曲 80 度から 40 度まで交互に伸展屈曲させ、角速 度 $140 / \mathrm{sec}$ （一秒間に 140 度動く速さ）で伸展 屈曲運動を各 10 回行ない筋電図を導出し、そ の平均值を評価した。

\section{設定条件}

1. 坐位

2. 大腿四頭筋、ハムストリングの表面筋電図

3. 他動的運動範囲

（肢位は膝屈曲 $80^{\circ}$ 位から $40^{\circ}$ までの往復 運動)

4. 屈曲伸展運動の間に十分の休止を設定

5. 角速度 : $140 / \mathrm{sec}$

6. 測定回数は各 10 回

症例は非家族性対麻瘏 2 例。両例とも下肢に 高度の痤性麻瘏を認める。また両例とも薬物治 療として十分量と考えられる筋弛緩剤を投与さ れている。

対 象

非家族性痙性対麻痺 2 例 


$\begin{array}{cll} & \text { 症例 } 1 & \text { 症例 } 2 \\ \text { 年 齢 ・ 性 } & 39 \cdot \text { 男 } & 59 \cdot \text { 男 } \\ \text { 経 過 年 数 } & 9 \text { 年 } & 5 \text { 年 } \\ \text { 痤性の部位 } & \text { 両下肢 } & \text { 両下肢 } \\ \text { 痤性の程度 } & \text { 高度 } & \text { 高度 } \\ \text { 歩 行 状 態 } & \text { 独歩可能 } & \text { 独步可能 } \\ \text { 薬物 治 療 } & + & + \\ \text { 良導絡治療 } & 1 \text { 回 } & \text { 12回 }\end{array}$

\section{治療内容}

良導絡自律神経調整療法……応良導点治療

刺鍼部位：両大腿前面、後面の反応良導点（経 穴) 計 8 所

刺激方法: 低周波置銊療法 $5 \mathrm{~Hz}$ 刺激 60 分

結果：症例 1 の結果である。上段は正常成人 コントロール、中段、下段は治療前後のハスト リング、大腿四頭筋の筋電図である。矢印の方 向は他動的運動範囲の方向を示しており、ハム ストリングは膝屈曲 80 度位から 40 度まで屈 曲、大腿四頭筋は 40 度から 80 度まで伸展した 時の筋電図が導出されている。治療前の両筋群 はコントロールと較べ、明らかに筋活動電位の 増加が認められる。治療後では治療前と較べ、 筋活動電位の相当的減少傾向が認められた。し かしながら自覚症状は不変であった。

症例 2 の結果である。症例 1 と同様に治療前 後で両筋群之あ筋活動電位の減少傾向を認め る。この症例は治療終了時、歩行時に両つまさ きのひっかかる感じが減少し、若亡歩行が楽に なったとうったえられた。

以上をまとめると筋活動電位の治療前後での 変化は症例 1 は八ムストリング、 55.0 から 26.8、大腿四頭筋は 40.6 から 13.6、症例 2 は八 ムストリング、23.6、15.8、大腿四頭筋 44.0、 11.4 と減少を認めた。以上から筋活動電位が本 治療前後で減少することが明らかになった。

\section{結 果}

平均筋活動電位 $(\mu \mathrm{v})$

治療前 治療後

Control Hamst. Quad.

症例 1 Hamst.
Quad.

40.6

13.6

症例 2 Hamst.

23.6

15.8

Quad.

44.0

\section{考 察}

以前より我々は両下肢痤性抑制を目的に良導 絡治療を継続してきており、臨床的に若干では あるがその効果を認めている1。本治療を含め た鍼治療の痤性抑制効果の検討は調べえた範井 では丹沢らが脳血管障害後遺症の上肢痤性に鍼 治療を施行し、効果判定の示表として歩行時の 时屈曲度、Brunnstrom stage、指鼻指試験の PATTERN と速度、ADL に一定の基準を授け 評価し、その効果を認めている2)。しかしながら 神経疾患の下肢痤性に対して筋訓練測定装置を 用い、鍼治療の痤性抑性効果を定量的に評価検 討した報告はない。

一般に痙性の評価は筋トーヌス、腱反射、ク ローヌスなど主観的判断にまかせているが、最 近、薬物療法の痤性に対する効果を筋訓練測定 装置を用い、定量的に検討されてきている゙3。

今回我々はこの装置を用いることにより、2 症例に本治療を試み、その痤性抑制効果を定量 的に評価した。結果より得られた筋電図所見が 直接、痤性のパターンや度合を現しているかど うか、検討が少ないこともあり現時点では不明 であるが、少なくとも両例とも臨床的に高度の 痤性を認め、結果として 2 例共、筋活動電位量 の相対的減少を認め、1例で臨床的にも歩行の 改善を認めたことは本治療法が痤性に対する一 治療法となりうることを示唆するものと考えら れた。

\section{結 語}

1. 非家族性痙性対麻症 2 例の両下肢痤性抑 制を目的に良導絡自律神経調整療法（銊治療） を施行し、筋訓練測定装置 (KIN-COM) を用 いて本療法の痙性抑制効果を定量的に評価し た。

2．両例に筋電図上、筋活動電位の相対的減 少を認め、症例 2 では自覚症状の改善を認め た。

3. 本療法が痙性抑制のための一治療手段と 
して有用である可能性を示唆した。

文 献

1）中根一好ら：スモン及び神経難病の痙性対 麻痷に対する良導絡自律神経調整療法の試 み。厚生省特定疾患スモン調査研究班平成 元年度研究業績集 P $352-355$.

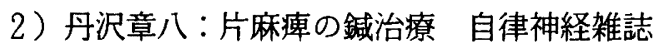

第 26 巻、P $128-135,1980$.

3) E.KNUTSSON : ANTIPARETIC AND ANTISPASTIC EFFECTS INDUCED BY TIZANIDINE IN PATIENTS WITH SPASTIC PARESIS. JOURNAL OF NEUROLOGICAL SCIENCES P 187204, 1982.

症例 1

Hamstring

Control

$$
\left.\begin{array}{ccc}
2 & 6 & 0 \\
\mu & v
\end{array}\right]
$$
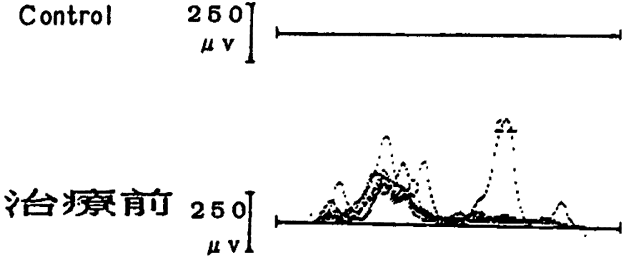

治痛察後

$$
250 .
$$
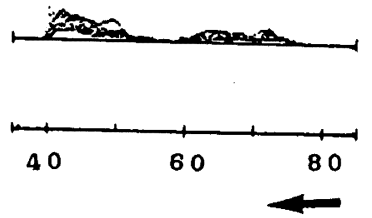

Hamstring

Control

$$
\left.\begin{array}{ccc}
2 & 5 & 0 \\
\mu & v
\end{array}\right]
$$

治痛等向
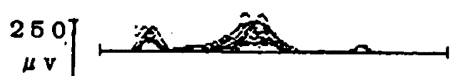

怔例 2
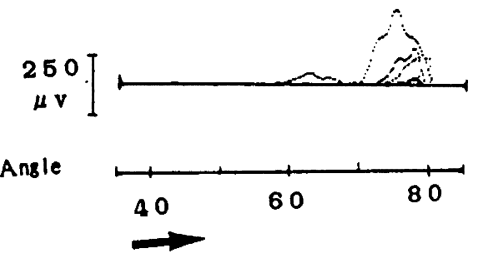

Ansle

- Quadriceps
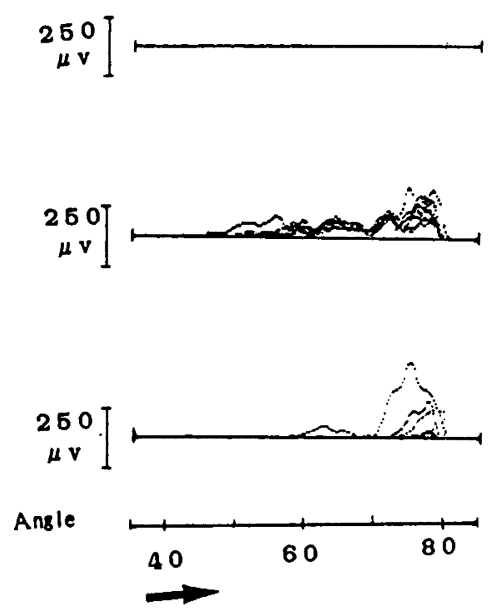
- 